\title{
CLAYEY SOIL AMENDMENT BY HYDROPHILIC NANO BENTONITE FOR LANDFILL COVER BARRIER: A CASE STUDY
}

\author{
Ahmad QASAIMEH ${ }^{1^{*}}$, Abdulla A. SHARO ${ }^{1}$, Khalid BANI-MELHEM ${ }^{2}$ \\ ${ }^{1}$ Department of Civil Engineering, Faculty of Engineering, Jordan University of Science and Technology, \\ Irbid 22110, Jordan \\ ${ }^{2}$ Department of Water Management and Environment, Faculty of Natural Resources and Environment, \\ The Hashemite University, P.O. Box 150459, Zarqa 13115, Jordan
}

Received 01 December 2019; accepted 19 February 2020

$>$ A clayey soil amended with hydrophilic nano bentonite material is being investigated to check its ability to serve as low cost landfill cover barrier.

The results showed that the addition of nano-clay at low percentages increases the strength of expansive soil, and decreases the swelling potential.

The intrinsic permeability of the amended soil was low enough.

The average values of hydraulic conductivity and gas transport coefficients were found as low as demanded by standards.

> The results attained in this work showed compatibility with standards.

It is recommended to use nano-clay amended clayey soils in landfills as low cost cover barriers.
}

\begin{abstract}
Methane and carbon dioxide are of major concern as greenhouse gases; the landfills have the problem of controlling these gases. Al Akaider in Jordan is the second biggest landfill suffers controlling gases as it lacks a cover design system. In this work, the main goal is to investigate the appropriateness of amended expansive clayey soil in Irbid as a cover barrier. The expansive soil is unwanted in construction projects, thus the modification of this expelled soil enables using it as a low cost landfill cover barrier. In this research, the effect of adding nano-clay material (Hydrophilic Nano Bentonite) on the geotechnical characteristics, hydraulic conductivity, and gas transport coefficients of the clayey soil are studied. The soil samples were obtained from Irbid city. Unconfined compressive strength and free swelling tests were performed on soil samples with different percentages of nano-clay added in the range $(0.1 \%$ to $1.2 \%)$ by weight. The results indicated that the addition of nano-clay at low percentages increases the strength of expansive soil up to $315 \mathrm{kPa}$ at $0.6 \%$ of nano-clay and the swelling potential decreased dramatically with the addition of nano-clay. The optimal percent of nano-clay was found to be $0.6 \%$. The intrinsic permeability of the amended soil was $6.03 \times 10^{-15} \mathrm{~m}^{2}$. The average values of fluid transport coefficients were determined at $25^{\circ} \mathrm{C}$. The hydraulic conductivity for water was about $6.5 \times 10^{-10} \mathrm{~m} / \mathrm{s}$. Gas conductivity coefficients for $\mathrm{CO}_{2}$ and $\mathrm{CH}_{4}$ were $5 \times 10^{-9} \mathrm{~m} / \mathrm{s}$ and $2.5 \times 10^{-9} \mathrm{~m} / \mathrm{s}$ respectively. Gas diffusion coefficients for $\mathrm{CO}_{2}$ and $\mathrm{CH}_{4}$ were $3 \times 10^{-6} \mathrm{~m}^{2} / \mathrm{s}$ and $4 \times 10^{-6} \mathrm{~m}^{2} / \mathrm{s}$ respectively.

The results obtained in this research showed compatibility with standards conducted on geosynthetic clay liner (GCL), consequently the amended Irbid soil investigated, can be used as a cover barrier in Al Akaider landfill. These findings can also be generalized to landfills with similar conditions.
\end{abstract}

Keywords: environmental sustainability, landfills, waste management technologies.

\section{Introduction}

The major problems of sanitary landfills are leachate and landfill gases. The cover layers have an important role in controlling these problems.
Landfill gases contributes to $18 \%$ of total greenhouse gases (GHGs) generated in the United States, it is the third after other sources from oil industry and fermentation (EPA, 2014). Methane is 30 times stronger than carbon

${ }^{*}$ Corresponding author. E-mail: argg22@yahoo.com 
dioxide as a greenhouse gas that contributes substantially to global warming (Didier et al., 2000; Mackie \& Cooper, 2009).

The barrier layer in the landfill cover system has the role of preventing the infiltration of precipitation that contributes to leachate formation; and also stopping the biogas migration into the atmosphere.

Biogas movement through the landfill cover is controlled by the permeability of the barrier in the cover system. The barrier in the cover system is chosen as geosynthetic clay liners (GCLs), where the voids are small and should be nearly saturated with water to mitigate biogas transport throughout the covering layers. However the field practice has demonstrated that unsaturated conditions are prospected to dominate in landfill cover system (Vangpaisal \& Bouazza, 2004; Bouazza \& Vangpaisal, 2003).

Expansive soil is known as shrink-swell soil, thus soil volume increases if exposed to water during the wet season. This increase in volume will produce uplift pressure under the foundations of the structure resting upon such a soil. During the dry seasons, expansive soil will shrink and consequently its volume will decrease. As a result, a severe damage may occur to the structure if this type of soil is not treated. Soil treatment, which includes soil stabilization by additives, is a well-known method in this field. As a new practice, the addition of fine particles at nano-scale, even at low dosages, can improve the properties of expansive soils (Taha, 2009).

During drying, the clayey soil shrinks and establishes matric suction in soil which forms cracks (Nahlawi \& Kodikara, 2006). The landfill barrier should be compacted at the maximum dry density and optimum water content to reduce shrinkage strain (Albrecht \& Benson, 2001). Many researches showed that the shrinkage strains are affected by soil composition and compaction status (Osinubi \& Nwaiwu, 2008; Albrecht \& Benson, 2001; Benson et al., 1994).

Another method to reduce soil shrinkage and to enhance its stabilization is to use additive materials such as fly ash, lime, nano-copper, nano-alumina, and nano clay (Coo et al., 2016; Taha \& Taha, 2012; Sharma et al., 2012; Wang et al., 2017).

Amendments are observed on the deformation and the flexural tensile strength of the soil barrier in landfills when using fiber additives within the barrier (Rajesh et al., 2014; Harianto et al., 2008)

This work entails a study conducted on an expansive clayey soil expelled from construction projects. The expansive soil is unwanted in construction projects due to swelling- shrinkage behavior, thus the amendment of this soil allows using it as a low cost material in other applications (Sharma \& Sivapullaiah, 2016; Yilmaz, 2015). The engineering properties of this soil can be improved by adding low percentages of hydrophilic nano-clay material to be used as landfill barrier in the cover system. The matter of having hydrophilic barrier will support the impermeability needed to prevent liquids percolating down and gases seeping up and enhances their collection in specific layers. The nano-clay material, for example, can also be recovered from the waste of stone cutting plants and stone quarries such as the research done by Sivrikaya et al. (2014). Applying these low cost materials and recovering them sustains the priority principle of reusing unwanted materials.

\section{The case study - Al Akaider landfill}

$\mathrm{Al}$ Akaider landfill is the second largest landfill in Jordan that was established in 1980s. It covers $80 \mathrm{ha}$, where it is located at a distance of $25 \mathrm{~km}$ east of Irbid city and about $1 \mathrm{~km}$ from the Jordanian / Syrian border at the coordinates $32^{\circ} 30^{\prime} 41.56^{\prime \prime} \mathrm{N}$ and $36^{\circ} 6^{\prime} 30.05^{\prime \prime} \mathrm{E}$ (Figures 1,2). The site is serving more than 70 towns and villages in northern Jordan (serving about 1Million capita). Although the processes are improved in comparison with the past practices, the landfill site is considered unsanitary, as it lacks any environmental protection measures and infrastructure; there are no leachate and gas collection systems at the site. Cover material is obtained from a designated on-site borrow area. It consists mainly of sandy soil and it is applied on a daily basis. Thickness of daily cover ranges between $30 \mathrm{~cm}-50 \mathrm{~cm}$ (Mediterranean Environmental Technical Assistance Program [METAP], 1998; Chopra et al., 2001).

The study area exhibits dry weather where the average temperature and rainfall pertains semi-arid to arid conditions. The topography of the study area is semi-flat located $650 \mathrm{~m}$ above the mean sea level (MSL). The average depth of the confined groundwater strata is located below $390 \mathrm{~m}$ of the ground surface with piezometric head of $400 \mathrm{~m}$ above the MSL. The effective vertical hydraulic conductivity ranges from $3.18 \times 10^{-6} \mathrm{~m} / \mathrm{sec}$ to $8.86 \times 10^{-5} \mathrm{~m} / \mathrm{sec}$, the landfill requires landfill gas collection system, storm water drainage network, and final capping and supplementary infrastructure facilities (Abu Rukah \& Al-Kofahi, 2001; METAP, 1998).

From this point of view, the landfill lacked to an engineered cover system, and here is the point of importance, that the soil in the place is not suitable for the cover system. On the other hand, unwanted Irbid soil that is expelled from engineering construction projects is the main concern in this work to play the role of the cover system. As the Irbid soil is an expansive clayey soil, it will serve better when modified by additives as it will be stronger, less swelling, and impermeable.

\section{Materials and methods}

\subsection{The expansive soil in Irbid}

The candidate soil for landfill cover system was obtained from the eastern part of Irbid city located in the northern part of Jordan. Irbid soil is well known to be highly expansive clayey soil with dominant smectite. The soil samples were taken from bits below $2.5 \mathrm{~m}$ from the eastern 


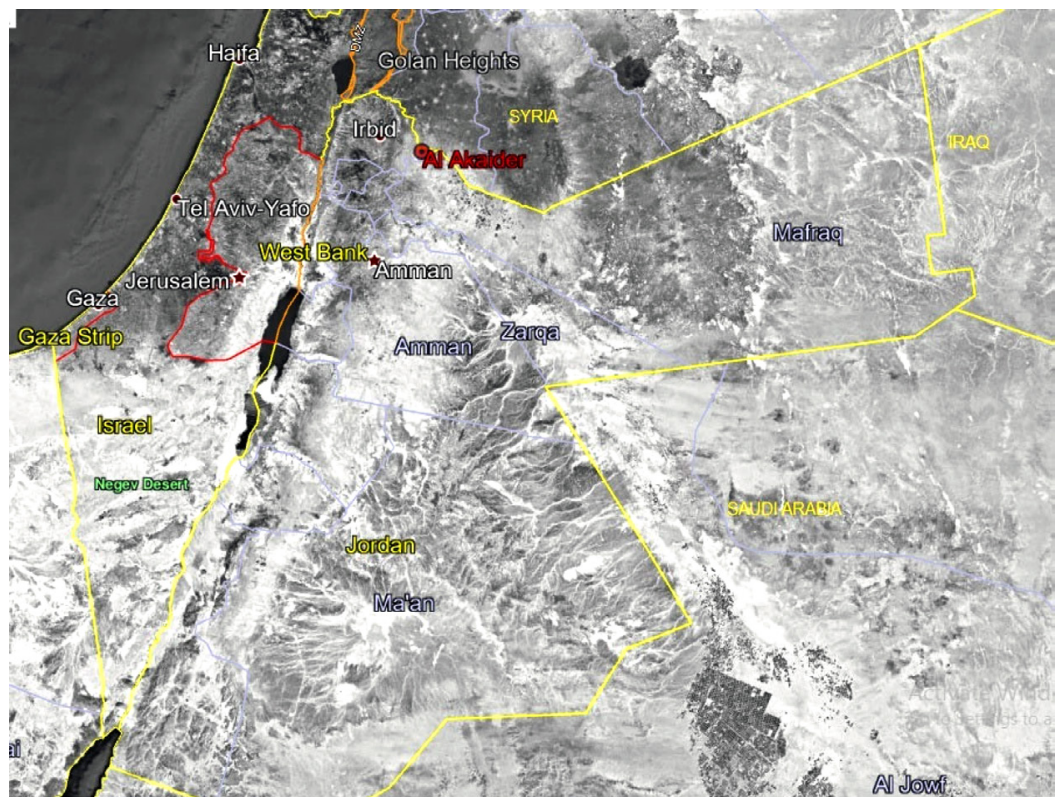

Figure 1. Al Akaider position at the Jordan map

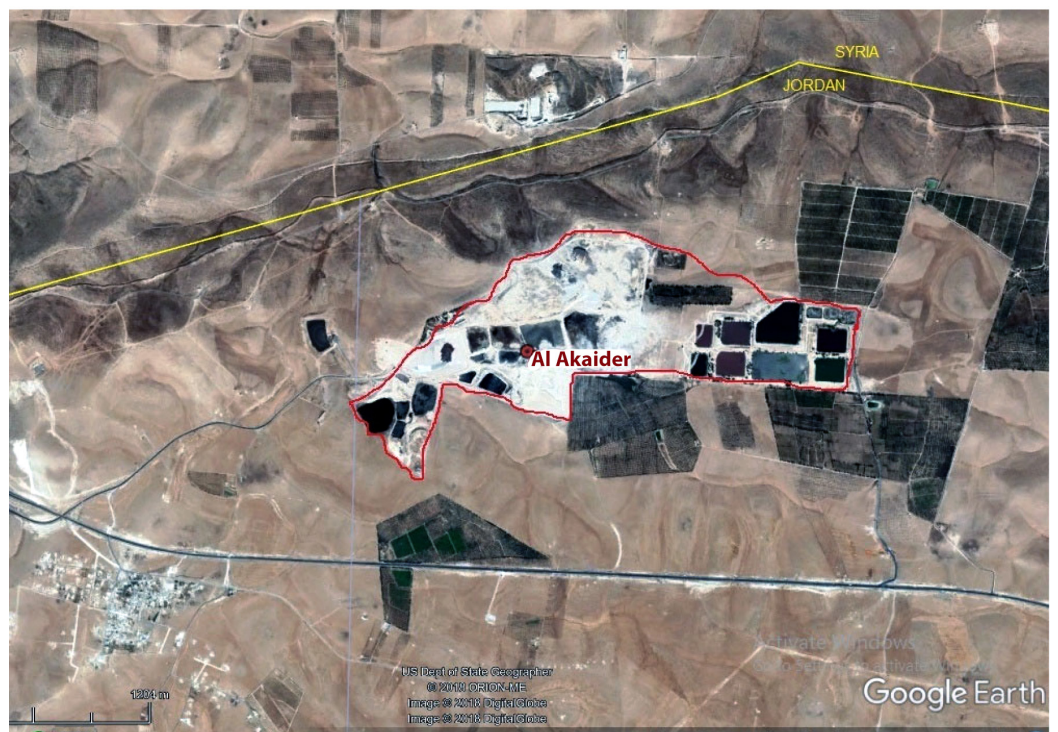

Avg. Temperature $\left({ }^{\circ} \mathrm{C}\right)$ Avg. Temperature $\left({ }^{\circ} \mathrm{F}\right)$ Precipitation / Rainfall (mm)

\begin{tabular}{|l|l|l|l|}
\hline January & 8.9 & 48.0 & 65 \\
\hline February & 9.8 & 49.6 & 62 \\
\hline March & 12.4 & 54.3 & 51 \\
\hline April & 16.2 & 61.2 & 15 \\
\hline May & 20.5 & 68.9 & 5 \\
\hline June & 23.8 & 74.8 & 0 \\
\hline July & 25.1 & 77.2 & 0 \\
\hline August & 25.5 & 77.9 & 0 \\
\hline September & 23.6 & 74.5 & 0 \\
\hline October & 20.4 & 68.7 & 8 \\
\hline November & 15.5 & 59.9 & 30 \\
\hline December & 10.4 & 50.7 & 61 \\
\hline
\end{tabular}

Figure 2. Al Akaider landfill area 
part of Irbid city. The soil was tested to find its physical properties, as shown in Table 1, according to specifications of American Society for Testing and Materials (ASTM D 7263, ASTM D 854, ASTM D 4318) (ASTM, 2009; ASTM, 2002; ASTM, 2005). The soil was tested to find its chemical components as shown in Table 2.

Table 1. Physical properties of Irbid soil

\begin{tabular}{|l|c|c|}
\hline \multicolumn{1}{|c|}{ Characteristic } & Standard & Value \\
\hline Specific Gravity & - & 2.67 \\
\hline Unit weight & $\mathrm{kN} / \mathrm{m}^{3}$ & 17.0 \\
\hline Liquid Limit (LL) & $\%$ & 64 \\
\hline Plastic Limit (PL) & $\%$ & 34 \\
\hline Plasticity Index (PI) & $\%$ & 31 \\
\hline Sand $(4.75-0.075) \mathrm{mm}$ & $\%$ & 19 \\
Silt $(0.075-0.002) \mathrm{mm}$ & $\%$ & 24 \\
Clay $(<0.002) \mathrm{mm}$ & $\%$ & 57 \\
\hline USCS classification & - & $\mathrm{CL}$ \\
\hline
\end{tabular}

Table 2. Chemical components of Irbid soil

\begin{tabular}{|c|c|c|}
\hline Chemical Component & Unit & Value \\
\hline $\mathrm{SiO}_{2}$ & $\%$ & 42.33 \\
$\mathrm{Al}_{2} \mathrm{O}_{3}$ & $\%$ & 12.92 \\
$\mathrm{CaO}$ & $\%$ & 10.66 \\
$\mathrm{Fe}_{2} \mathrm{O}_{3}$ & $\%$ & 8.68 \\
$\mathrm{MgO}_{\mathrm{TiO}}$ & $\%$ & 2.59 \\
$\mathrm{~K}_{2} \mathrm{O}$ & $\%$ & 1.34 \\
$\mathrm{P}_{2} \mathrm{O}_{5}$ & $\%$ & 0.94 \\
$\mathrm{MnO}$ & $\%$ & 0.16 \\
$\mathrm{Na}_{2} \mathrm{O}$ & $\%$ & 0.15 \\
& $\%$ & 0.11 \\
\hline
\end{tabular}

\subsection{The nano-clay material}

The nano-clay material (Hydrophilic Nano Bentonite) was used as an additive material in this study. The small size and hydrophillicity makes it good candidate to act as impermeable material. The specifications for the nano-clay material are listed in Table 3.

Table 3. Properties of hydrophilic nano-clay bentonite

\begin{tabular}{|l|c|}
\hline \multicolumn{1}{|c|}{ Property } & Standard \\
\hline Appearance (Color) & Light tan to brown \\
\hline Appearance (form) & Powder \\
\hline Aspect ratio & $300-500$ \\
\hline Specific Gravity & 2.88 \\
\hline Loss on Drying & $<18.0 \%$ \\
\hline Average Particle Size & $<25$ micron \\
\hline
\end{tabular}

\subsection{Soil testing}

The soil samples were exposed to several tests. The compaction test was conducted according to ASTM D698 (ASTM, 2012) on the basic soil and the amended soils with nano-clay additives $(0.1 \%, 0.2 \%, 0.3 \%, \ldots 1.2 \%)$. Soil samples are put in three layers in the standard mold by which each layer is compacted by 25 blows of a $2.5 \mathrm{~kg}$ hammer dropped from a distance of $304.8 \mathrm{~mm}$, exerting about $600 \mathrm{kN} \cdot \mathrm{m} / \mathrm{m}^{3}$, by which the maximum dry density and optimum moisture content values were obtained. Then swelling potential tests were performed according to ASTM D4546 (ASTM, 2014). The oven-dried soil samples are mixed homogenously with distilled water and packed in a consolidation ring of $20 \mathrm{~mm}$ thickness and $75 \mathrm{~mm}$ diameter and compacted to obtain the required volume. Filter paper and porous stone were placed on each face of the sample. Dial gauge was set to zero and then distilled water was added to the sample. The change in dial gauge readings was taken at different time intervals up to constant dial gauge reading. After that, a load was applied on the specimen to obtain the swelling pressure needed to compress the sample to its original height.

The capability of nano-clay additives in reducing the swelling potential of expansive soils is then recognized. The swelling potential was estimated as a percentage according to the following equation:

$$
\text { Swelling percentage }=\frac{\Delta h}{h} \times 100 \%,
$$

where: $\Delta h$ is the swelling increase (the increase in the height of the tested soil sample); and $h$ is the original height of the soil sample.

The unconfined compressive strength test was conducted according to ASTM D2166 (ASTM, 2013) on samples compacted to their specific maximum dry density and optimum moisture content values obtained from the compaction test. Soil samples were mixed thoroughly with distilled water and packed in a mold of $36 \mathrm{~mm}$ diameter and $89 \mathrm{~mm}$ height and compacted to obtain the required volume. Each soil specimen was placed centrally between the two loading plates and dial gauges were set to zero. Load dial gauge readings were taken at different strain values till load reached a maximum value and remained approximately constant.

\subsection{Theory of fluid transport in porous media}

The fluid transports by convection in the porous media due to pressure gradient. The flow can be defined by Darcy formula as expressed by in the following equation (Bear, 2018):

$$
Q=\frac{K A}{\rho g} \frac{d P}{d L},
$$

where: $Q$ is the fluid discharge in $\mathrm{m}^{3} / \mathrm{s}, d P / d L$ is the pressure gradient in $\mathrm{Pa} / \mathrm{m}, A$ is the cross sectional area in $\mathrm{m}^{2}$, $\rho$ is the fluid density in $\mathrm{kg} / \mathrm{m}^{3}, g$ is the gravity acceleration in $\mathrm{m} / \mathrm{s}^{2}$, and $\mathrm{K}$ is the conductivity coefficient in $\mathrm{m} / \mathrm{s}$.

The conductivity coefficient is a dependent on the properties of both soil media and flowing fluid. The conductivity coefficient can be expressed in the following equation (Carman, 1956):

$$
K=\frac{k \rho g}{\mu},
$$


where: $k$ is the intrinsic permeability of the soil media in $\mathrm{m}^{2}, \mu$ is the absolute viscosity of the flowing fluid in Pa.s.

By combination between Eq. (1) and Eq. (2) at constant temperature, the following equation can be obtained:

$$
Q=\frac{k}{\mu} A \frac{d P}{d L} .
$$

For the effect of porosity and water content on gas conductivity coefficient, the following equation represents the coefficient of conductivity of gas in porous media as a function of gas properties, media properties, and water content $(\theta)$ :

$$
K(\theta)=\left(\frac{k \rho g}{\mu}\right) k_{r}(\theta),
$$

where: $k r(\theta)$ is the gas relative permeability (dimensionless, ranges from 0 to 1) (Stephens, 1996).

The intrinsic permeability $(k)$ of the soil is dependent on the soil porosity and the diameter of the soil particle, the intrinsic permeability can be expressed by the following formula by Kozeny-Carmen:

$$
k=\frac{1}{180} \frac{\varepsilon^{3}}{(1-\varepsilon)^{2}} d_{p}^{2},
$$

where: $d_{p}(\mathrm{~m})$ is diameter of soil particle, $\varepsilon$ is the porosity (Reible, 2017).

In diffusion, gas transport occurs due to concentration gradient, where the gas diffuses and redistributes from the higher concentrated area to the lower concentrated area until steadiness is attained. The diffusion rate is primarily represented by Fick's first law:

$$
F_{g}=-D \frac{\partial C}{\partial Z}
$$

where: $F_{g}$ is the mass flow rate per unit area $\left(\mathrm{kg} / \mathrm{s} . \mathrm{m}^{2}\right) ; C$ is the concentration of the diffusing gas $\left(\mathrm{kg} / \mathrm{m}^{3}\right) ; Z$ is the space coordinate $(\mathrm{m}), D$ is the diffusion coefficient $\left(\mathrm{m}^{2} / \mathrm{s}\right)$ (Bouazza \& Vangpaisal, 2003).

The porosity and the water content are very important factors are encountered while the gas transports in the soil owing their effect on the coefficient of diffusion and coefficient of conductivity and subsequently their effect on the overall transport. For the effect of porosity and water content on diffusion coefficient, the water-induced linear reduction (WLR) formula based on Marshall (1959) is describing the effect:

$$
\frac{D_{p}}{D_{0}}=\frac{\varepsilon^{2.5}}{(\varepsilon+\theta)},
$$

where: $D_{p}$ is the gas diffusion coefficient in the soil, $D_{0}$ is the gas diffusion coefficient in the air, $\varepsilon$ is the soil porosity $\left(\mathrm{cm}^{3}\right.$ soil air $/ \mathrm{cm}^{3}$ soil), $\theta$ is the volumetric water content $\left(\mathrm{cm}^{3} / \mathrm{cm}^{3}\right)$.

\section{Results and discussion}

\subsection{Effect of nano-clay additives on soil strength characteristics and swelling potential}

The geotechnical characteristics of natural bare Irbid soil (Table 4) were obtained by conducting compaction test, unconfined compressive strength test, and swelling potential test. These geotechnical parameters were also obtained for amended soil at different additive percentages as it will be seen in the next figures.

Table 4. Geotechnical characteristics of natural Irbid clayey soil

\begin{tabular}{|l|c|c|}
\hline \multicolumn{1}{|c|}{ Geotechnical parameter } & Unit & Value \\
\hline Initial water content & $\%$ & 14 \\
Unconfined compressive strength & $\mathrm{kPa}$ & 222 \\
\hline Maximum dry unit weight & $\mathrm{kN} / \mathrm{m}^{3}$ & 15.5 \\
Optimum moisture content & $\%$ & 23.2 \\
\hline Swelling potential & $\%$ & 28.4 \\
\hline
\end{tabular}

The effect of nano-clay on the strength of expansive soil was examined by measuring the unconfined compressive strength of soil without and with nano-clay additives at different percentages $(0.1,0.2,0.3, \ldots, 1.2 \%)$. Figure 3 shows the effect of different clay percentages on the unconfined compressive strength of expansive soil.

It can be observed from Figure 3, that the addition of small dosage of nano-clay particles of about $0.6 \%$, the unconfined compressive strength of soil reaches $315 \mathrm{kPa}$ with about $45 \%$ increase of initial value without nanoclay addition. According to the specifications of generally used compacted clay liners, Daniel and Wu (1993) suggested that the unconfined compressive strength should be greater than $200 \mathrm{kPa}$. Hence, the obtained value of the unconfined compressive strength for nano-clay amended clayey soil is overwhelming.

The increase in the unconfined compressive strength can be interpreted as the nano-clay material acts as fastening agent that ties soil particles together and decreases dispersivity potential as it is described in the research by Abbasi et al. (2018). However, at higher dosages, the hydrophilic nano-clay will be surrounded with higher

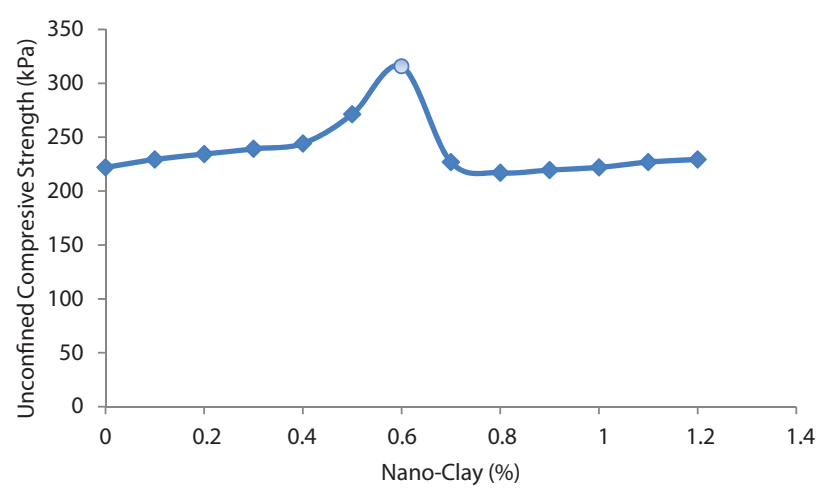

Figure 3. Effect of different nano-clay percentages on unconfined compressive strength 
amount of water that prevents the nano particles from functioning well, with an increased nano-clay, the mechanical properties decreased due to the agglomeration of excessive nano-clay as what is explained by Gabr et al. (2013), and this explains the drawdown of the unconfined compressive strength value to about its initial value.

The other important issue in this investigation, is to test the capability of nano-clay material in reducing the swelling potential of expansive clayey soils. Figure 4 shows a significant reduction in swelling percentage associated with the addition of nano-clay material.

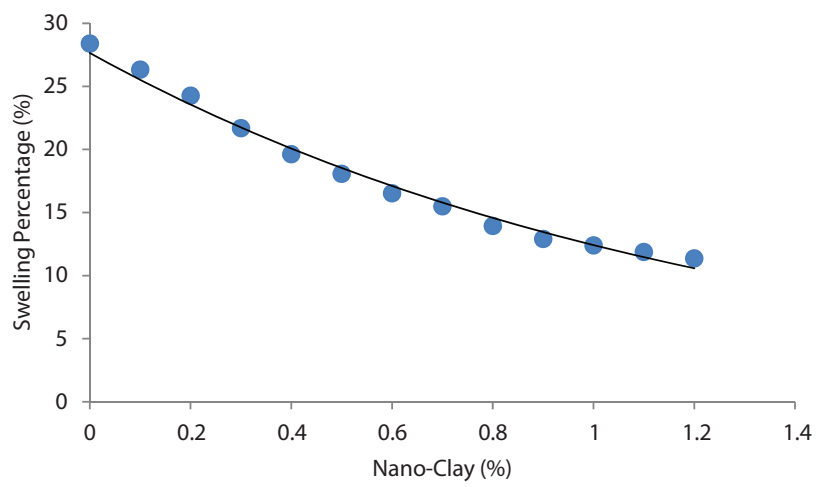

Figure 4. The Effect of different nano-clay percentages on swelling percentage

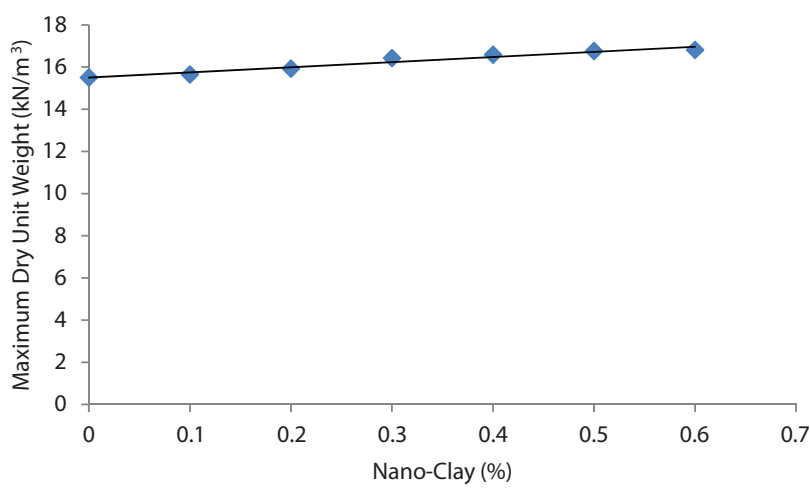

Figure 5. The effect of different nano-clay percentages on the maximum dry unit weight

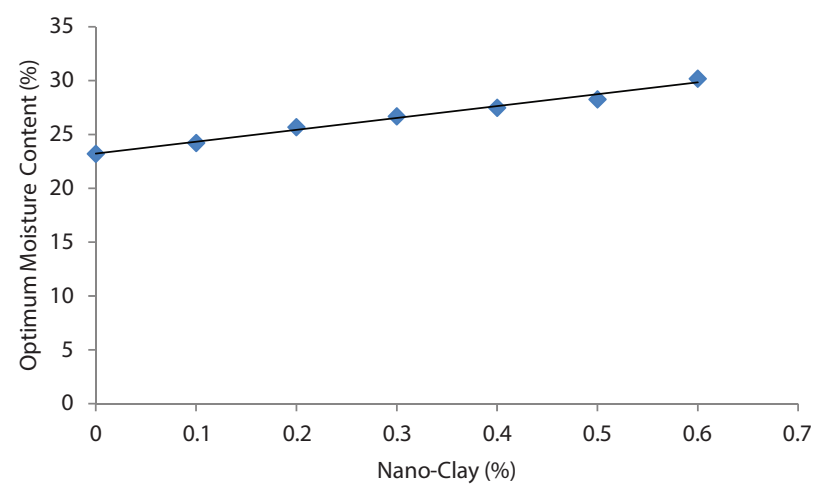

Figure 6. The effect of different nano-clay percentages on the optimum moisture content
The enhancement of soil by reducing swelling potential has been achieved and it can be explained as that the nano-clay particles will lay in the soil intraparticle voids, and thus by the addition of water, the hydrophilic nanoclay particles will absorb most of water and prevents it from interacting with soil particles. Consequently, nanoclay particles will expand within the soil intraparticle voids retaining most of the increase in volume within the voids. In addition, it should be pointed out that the high ratio of surface to volume exists at the nano scale will cause the nano particles to interact with other soil particles. The number of spaces between clay particles reduces and the size of the voids will be smaller, and the new binding between clay particles relocates the microstructure of the expansive clayey soil (Cheng et al., 2020).

On other domain, the addition of nano-clay material increases the dry density and the optimum moisture content of the soil as it can be seen in the Figures 5 and 6 . This rise in the maximum dry unit weight is due to the higher specific gravity of the nano-clay bentonite, whereas the optimum moisture content increases due to the hydrophilicity of the nano-clay bentonite. Adding nano-clay material sustains conditions that stimulate the clayey soil to act more unified and less permeable, e.g. a work done by Kananizadeh et al. (2011).

\subsection{Calculated biogas transport in amended soil barrier}

In this work, the nano-clay amended soil is being investigated to check its intrinsic permeability and hydraulic conductivity as well as its permeability and diffusion coefficients for gases at different temperatures. The viscosities of methane and carbon dioxide at different temperatures are shown in Table 5. The intrinsic permeability is estimated here using Kozeny-Carman equation, the coefficients of conductivity is estimated using equation by Carman (1956), and the coefficients of diffusion is estimated using (WLR) model based on Marshall (1959) model.

Table 5. Methane and carbon dioxide viscosities at different temperatures

\begin{tabular}{|c|c|c|}
\hline \multirow{2}{*}{ Temperature $\left({ }^{\circ} \mathrm{C}\right)$} & \multicolumn{2}{|c|}{ Viscosity $\left(\mathrm{m}^{2} / \mathrm{s}\right)$} \\
\cline { 2 - 3 } & $\mathrm{CH}_{4}$ & $\mathrm{CO}_{2}$ \\
\hline 0 & $14.47 \times 10^{-6}$ & $7.02 \times 10^{-6}$ \\
\hline 20 & $16.54 \times 10^{-6}$ & $8.09 \times 10^{-6}$ \\
\hline 25 & $17.07 \times 10^{-6}$ & $8.36 \times 10^{-6}$ \\
\hline
\end{tabular}

The intrinsic permeability of amended soil is found to be $6.03 \times 10^{-15} \mathrm{~m}^{2}$, in general tests, the laboratory intrinsic permeability of different types of GCLs using nitrogen gas varies approximately between $1 \times 10^{-12}$ and $1 \times 10^{-19} \mathrm{~m}^{2} / \mathrm{s}$, depending on the applied confining stress and the water content (Bouazza \& Vangpaisal, 2003; Bouazza, 2002; Pitanga et al., 2011; Vangpaisal et al., 2002). The calculated intrinsic permeability of amended soil satisfies the required value needed for barriers. 
The hydraulic conductivity of the soil barrier increases while the temperature increases (Figure 7). The hydraulic conductivity values of the amended soil are estimated in the range $\left(3.2 \times 10^{-10}\right.$ to $\left.6.5 \times 10^{-10} \mathrm{~m} / \mathrm{s}\right)$ varying with temperature. Daniel \& Benson (1990) indicated in their research findings that hydraulic conductivity of the value less than $1 \times 10^{-9} \mathrm{~m} / \mathrm{s}$ is essential for the compacted clay liners.

The flow of water permeated through amended soil barrier can be estimated using Darcy equation (Figure 8). As the barrier layer is bounded with permeable layer for water drainage above it, the flow permeation is expected minimal.

The coefficient of permeability of methane is less than that of carbon dioxide and both are adversely affected by temperature (Figure 9). The values of gas permeability coefficients at $25{ }^{\circ} \mathrm{C}$ for $\mathrm{CO}_{2}$ and $\mathrm{CH}_{4}$ are $5 \times 10^{-9} \mathrm{~m} / \mathrm{s}$ and $2.5 \times 10^{-9} \mathrm{~m} / \mathrm{s}$ respectively. Laboratory gas permeability coefficient of different types of GCLs using nitrogen gas varies approximately between $1 \times 10^{-7}$ and $1 \times 10^{-13} \mathrm{~m} / \mathrm{s}$, depending on applied confining stress and the water content (Vangpaisal \& Bouazza, 2004; Bouazza et al., 2017)

The coefficient of diffusion of methane is higher than that of carbon dioxide and both are proportionally affected by temperature (Figure 10). The values of gas diffusion coefficients at $25^{\circ} \mathrm{C}$ for $\mathrm{CO}_{2}$ and $\mathrm{CH}_{4}$ are $3 \times 10^{-6} \mathrm{~m}^{2} / \mathrm{s}$ and $4 \times 10^{-6} \mathrm{~m}^{2} / \mathrm{s}$ respectively. Laboratory gas diffusion coefficient of GCLs was around $1 \times 10^{-6} \mathrm{~m}^{2} / \mathrm{s}$ on different confining stresses and about 25\% water content (Bouazza et al., 2017; Bouazza \& Rahman, 2007).

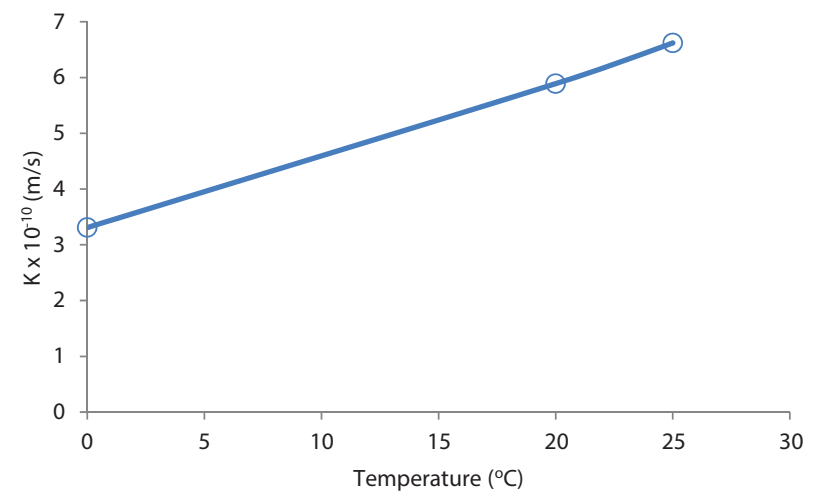

Figure 7. The hydraulic conductivity coefficient for barrier at different temperatures

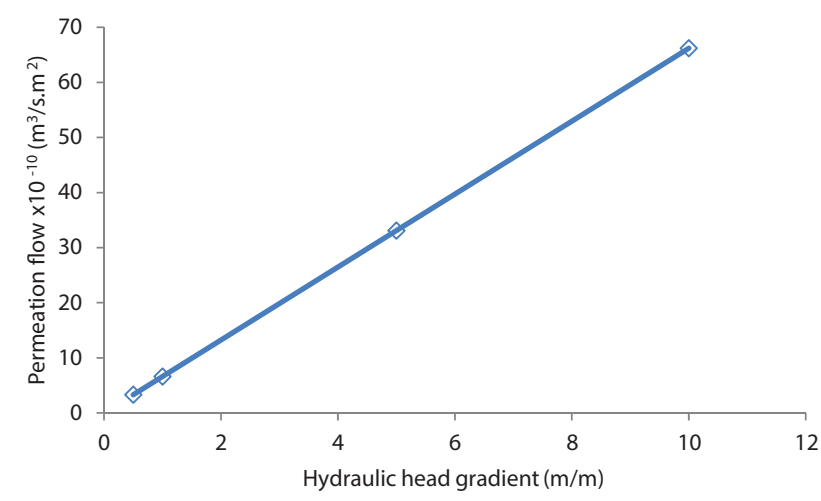

Figure 8. Permeation flux of water through barrier at different hydraulic head gradients

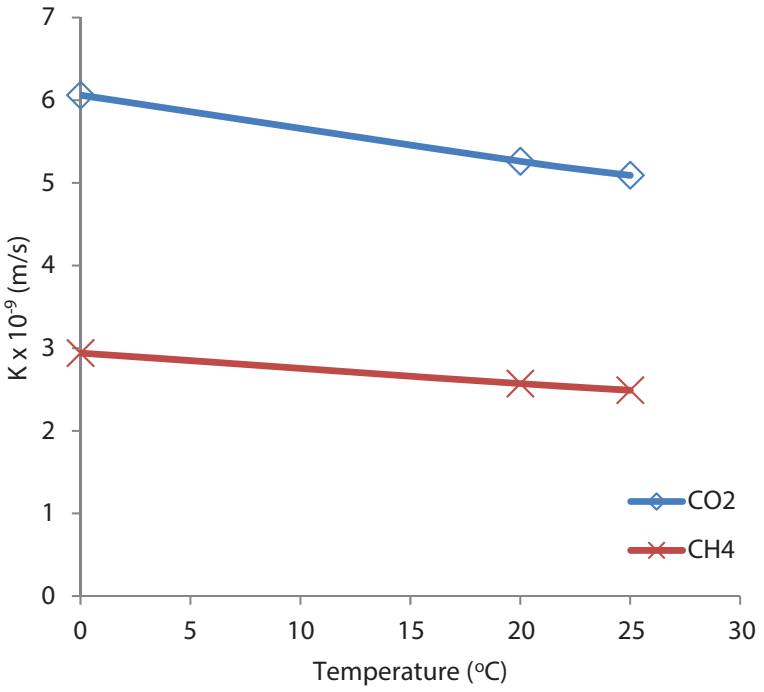

Figure 9. The biogas permeability coefficients for barrier at different temperatures

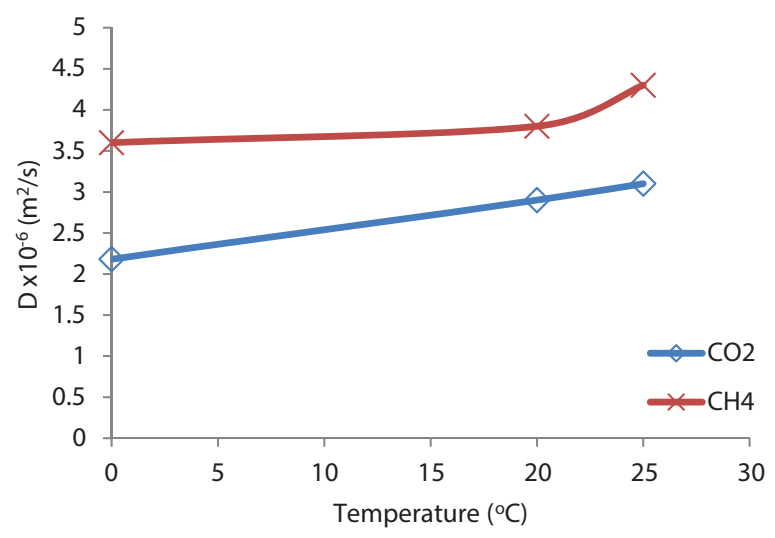

Figure 10. The biogas diffusion coefficient for barrier at different temperatures

\section{Barrier design}

As the waste degrades in the landfill, biogas moves by convection and diffusion. The driving force for convection is the pressure gradient, while the driving force for diffusion is the concentration gradient. The typical approaches used in an attempt to control landfill gas, is to control it by barriers integrated with either passive or active landfill gas collection system. The typical cover system must have gas collection layer,

Above which, there should be an impermeable layer acting as a barrier, so that it prevents gases to escape to upper zones, and at the same time it prevents percolated water from above layers from seeping down to form leachate (Figure 11). As per US EPA, the barrier should have hydraulic conductivity of no more than $1 \times 10^{-7} \mathrm{~cm} / \mathrm{s}$ with a final soil cover of 3 feet or thicker of clay and/or geomembrane cover system (EPA, 2011).

With the addition of $0.6 \%$ nano-clay material to the clayey soil, the obtained amended soil has the following properties summarized in Table 6.

The results attained in this work showed compatibility with standards, and thus it is recommended to use 


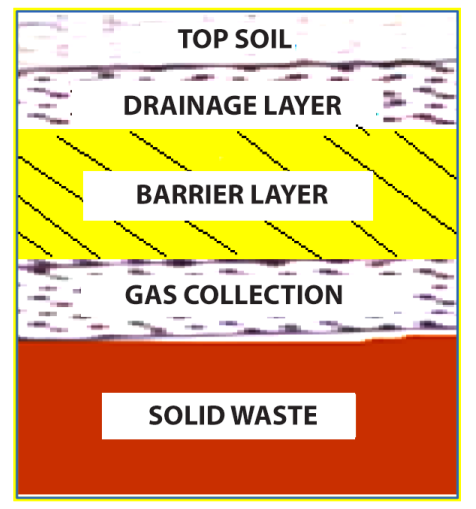

Figure 11. The design of cover system with barrier layer

Table 6. Geotechnical properties of nano-clay amended Irbid clayey soil

\begin{tabular}{|l|c|c|}
\hline \multicolumn{1}{|c|}{ Property } & Unit & Value \\
\hline Specific gravity & - & 2.77 \\
\hline Porosity & - & 0.44 \\
\hline intrinsic permeability & $\mathrm{m}^{2}$ & $6.03 \times 10^{-15}$ \\
\hline Unconfined compressive strength & $\mathrm{kPa}$ & 315.7 \\
\hline Optimum moisture content & $\%$ & 30.2 \\
\hline Maximum dry unit weight & $\mathrm{kN} / \mathrm{m}^{3}$ & 16.8 \\
\hline Swelling potential & $\%$ & 16.5 \\
\hline
\end{tabular}

nano-clay amended clayey soils in landfills as low cost cover barriers. Furthermore, as a vital perspective, it is recommended to apply the reuse principle by exchanging nano-clay wastes from stone cutting plants and stone quarry tailings to be used in amending clayey soil as that work conducted by Sivrikaya et al. (2014). In addition, one of the perspectives of this research is to check the ability of amended clayey soil to act as bottom liner in the landfill and its ability to endure leachate acidity or basicity. Some other future outlook is to apply other different types of soils and wastes to be applied as layers for landfill construction such as gases collection layers.

\section{Conclusions}

In this research, amended clayey soil is being investigated to check its ability to serve as low cost landfill barrier. A hydrophilic nano-clay bentonite material is added to the clayey soil to improve its geotechnical characteristics, hydraulic conductivity, and gas transport coefficients. The results showed that the addition of nano-clay at low percentages increases the strength of expansive soil, and decreases the swelling potential. At the same time, the intrinsic permeability of the amended soil, the average values of hydraulic conductivity, and gas transport coefficients were found as low as demanded by standard specifications. It is recommended to use nano-clay amended clayey soils in landfills as low cost cover barriers especially when the nano-clay are diverted from stone tailings.

\section{Acknowledgements}

The authors appreciate the assistance of Bashar BaniKhaled and Yousef Al-Houidi for their efforts during the laboratory tests.

\section{References}

Abbasi, N., Farjad, A., \& Sepehri, S. (2018). The use of nanoclay particles for stabilization of dispersive clayey soils. Geotechnical and Geological Engineering, 36(1), 327-335.

https://doi.org/10.1007/s10706-017-0330-9

Abu-Rukah, Y., \& Al-Kofahi, O. (2001). The assessment of the effect of landfill leachate on ground-water quality - a case study. El-Akader landfill site - north Jordan. Journal of Arid Environments, 49(3), 615-630. https://doi.org/10.1006/jare.2001.0796

Albrecht, B. A., \& Benson, C. H. (2001). Effect of desiccation on compacted natural clays. Journal of Geotechnical and Geoenvironmental Engineering, 127(1), 67-75. https://doi.org/10.1061/(ASCE)1090-0241(2001)127:1(67)

ASTM. (2002). D854-02. Standard test method for specific gravity of soil solids by water pycnometer. Annual Book of ASTM Standards. ASTM International, West Conshohocken, PA.

ASTM. (2005). D4318. Standard test method for liquid limit, plastic limit, and plasticity index of soils. ASTM International, West Conshohocken, PA.

ASTM. (2009). D7263-09. Standard test method for laboratory determination of density (unit weight) of soil specimens. ASTM International, West Conshohocken, PA.

ASTM. (2012). D698. Standard test methods for laboratory compaction characteristics of soil using standard effort. ASTM International, West Conshohocken, PA.

ASTM. (2013). D. 2166/D 2166M. Standard test method for unconfined compressive strength of cohesive soil. ASTM International, West Conshohocken, PA.

ASTM. (2014). D4546-14. Standard test methods for one-dimensional swell or collapse of soils. ASTM Book of Standard Specifications, Designation.

Bear, J. (2018). Modeling phenomena of flow and transport in porous media (Vol. 31). Springer. https://doi.org/10.1007/978-3-319-72826-1

Benson, C. H., Zhai, H., \& Wang, X. (1994). Estimating hydraulic conductivity of compacted clay liners. Journal of Geotechnical Engineering, 120(2), 366-387. https://doi.org/10.1061/(ASCE)0733-9410(1994)120:2(366)

Bouazza, A. (2002). Geosynthetic clay liners. Geotextiles and Geomembranes, 20(1), 3-17. https://doi.org/10.1016/S0266-1144(01)00025-5

Bouazza, A., \& Rahman, F. (2007). Oxygen diffusion through partially hydrated geosynthetic clay liners. Géotechnique, 57(9), 767-772. https://doi.org/10.1680/geot.2007.57.9.767

Bouazza, A., \& Vangpaisal, T. (2003). An apparatus to measure gas permeability of geosynthetic clay liners. Geotextiles and Geomembranes, 21(2), 85-101. https://doi.org/10.1016/S0266-1144(02)00058-4

Bouazza, A., Rouf, M. A., Singh, R. M., Rowe, R. K., \& Gates, W. P. (2017). Gas advection-diffusion in geosynthetic clay liners with powder and granular bentonites. Geosynthetics International, 24(6), 607-614. https://doi.org/10.1680/jgein.17.00027

Carman, P. C. (1956). Flow of gases through porous media. Academic Press. 
Cheng, G., Zhu, H. H., Wen, Y. N., Shi, B., \& Gao, L. (2020). Experimental investigation of consolidation properties of nano-bentonite mixed clayey soil. Sustainability, 12(2), 459. https://doi.org/10.3390/su12020459

Chopra, M., Reinhart, D., \& El-Shaar, W. (2001). US-Jordan municipal solid waste management collaborative research (Final report). The National Science Foundation (NSF).

Coo, J. L., So, Z. P., \& Ng, C. W. (2016). Effect of nanoparticles on the shrinkage properties of clay. Engineering Geology, 213, 84-88. https://doi.org/10.1016/j.enggeo.2016.09.001

Daniel, D. E., \& Benson, C. H. (1990). Water content-density criteria for compacted soil liners. Journal of Geotechnical Engineering, 116(12), 1811-1830.

https://doi.org/10.1061/(ASCE)0733-9410(1990)116:12(1811)

Daniel, D. E., \& Wu, Y. K. (1993). Compacted clay liners and covers for arid sites. Journal of Geotechnical Engineering, 119(2), 223-237. https://doi.org/10.1061/(ASCE)0733-9410(1993)119:2(223)

Didier, G., Bouazza, A., \& Cazaux, D. (2000). Gas permeability of geosynthetic clay liners. Geotextiles and Geomembranes, $18(2$ 4), 235-250. https://doi.org/10.1016/S0266-1144(99)00029-1

EPA. (2011). Available and emerging technologies for reducing greenhouse gas emissions from municipal solid waste landfills. https://www.epa.gov/sites/production/files/2015-12/documents/landfills.pdf

EPA. (2014). Inventory of US greenhouse gas emissions and sinks: 1990-2012. The Air Pollution Consultant, 24(3), 1_17$1 \_22$.

Gabr, M. H., Phong, N. T., Abdelkareem, M. A., Okubo, K., Uzawa, K., Kimpara, I., \& Fujii, T. (2013). Mechanical, thermal, and moisture absorption properties of nano-clay reinforced nano-cellulose biocomposites. Cellulose, 20(2), 819826. https://doi.org/10.1007/s10570-013-9876-8

Harianto, T., Hayashi, S., Du, Y. J., \& Suetsugu, D. (2008). Effects of fiber additives on the desiccation crack behavior of the compacted Akaboku soil as a material for landfill cover barrier. Water, Air, and Soil Pollution, 194(1-4), 141-149. https://doi.org/10.1007/s11270-008-9703-2

Kananizadeh, N., Ebadi, T., Khoshniat, S. A., \& Mousavirizi, S. E. (2011). The positive effects of nanoclay on the hydraulic conductivity of compacted Kahrizak clay permeated with landfill leachate. Clean-Soil, Air, Water, 39(7), 605-611.

https://doi.org/10.1002/clen.201000298

Mackie, K. R., \& Cooper, C. D. (2009). Landfill gas emission prediction using Voronoi diagrams and importance sampling. Environmental Modelling \& Software, 24(10), 1223-1232. https://doi.org/10.1016/j.envsoft.2009.04.003

Marshall, T. J. (1959). The diffusion of gases through porous media. Journal of Soil Science, 10(1), 79-82. https://doi.org/10.1111/j.1365-2389.1959.tb00667.x

Mediterranean Environmental Technical Assistance Program. (1998). Northern Region Solid Waste Management Study (Supplementary Data Report).

Nahlawi, H., \& Kodikara, J. K. (2006). Laboratory experiments on desiccation cracking of thin soil layers. Geotechnical \& Geological Engineering, 24(6), 1641-1664.

https://doi.org/10.1007/s10706-005-4894-4
Osinubi, K. J., \& Nwaiwu, C. M. (2008). Desiccation-induced shrinkage in compacted lateritic soils. Geotechnical and Geological Engineering, 26(5), 603-611.

https://doi.org/10.1007/s10706-008-9193-4

Pitanga, H. N., Pierson, P., \& Vilar, O. M. (2011). Measurement of gas permeability in geosynthetic clay liners in transient flow mode. Geotechnical Testing Journal, 34(1), 27-33. https://doi.org/10.1520/GTJ103000

Rajesh, S., Gourc, J. P., \& Viswanadham, B. V. S. (2014). Evaluation of gas permeability and mechanical behaviour of soil barriers of landfill cap covers through laboratory tests. Applied Clay Science, 97, 200-214. https://doi.org/10.1016/j.clay.2014.04.041

Reible, D. (2017). Fundamentals of environmental engineering. CRC Press. https://doi.org/10.1201/9780203755303

Sharma, A. K., \& Sivapullaiah, P. V. (2016). Ground granulated blast furnace slag amended fly ash as an expansive soil stabilizer. Soils and Foundations, 56(2), 205-212. https://doi.org/10.1016/j.sandf.2016.02.004

Sharma, N. K., Swain, S. K., \& Sahoo, U. C. (2012). Stabilization of a clayey soil with fly ash and lime: a micro level investigation. Geotechnical and Geological Engineering, 30(5), 11971205. https://doi.org/10.1007/s10706-012-9532-3

Sivrikaya, O., Kıyıldı, K. R., \& Karaca, Z. (2014). Recycling waste from natural stone processing plants to stabilise clayey soil. Environmental Earth Sciences, 71(10), 4397-4407. https://doi.org/10.1007/s12665-013-2833-x

Stephens, D. B. (1996). Characterizing hydraulic properties. In Vadose Zone Hydrology (1st ed., pp. 183-187). CRC Press.

Taha, M. R. (2009). Geotechnical properties of soil-ball milled soil mixtures. In Nanotechnology in Construction 3 (pp. 377382). Springer. https://doi.org/10.1007/978-3-642-00980-8_51

Taha, M. R., \& Taha, O. M. E. (2012). Influence of nano-material on the expansive and shrinkage soil behavior. Journal of $\mathrm{Na}$ noparticle Research, 14, 1190. https://doi.org/10.1007/s11051-012-1190-0

Vangpaisal, T., \& Bouazza, A. (2004). Gas permeability of partially hydrated geosynthetic clay liners. Journal of Geotechnical and Geoenvironmental Engineering, 130(1), 93-102. https://doi.org/10.1061/(ASCE)1090-0241(2004)130:1(93)

Vangpaisal, T., Bouazza, A., \& Kodikara, J. (2002). Gas permeability of a needle punched geosynthetic clay liner subjected to wetting and drying. In International Conference on Geosynthetics 2002 (pp. 841-844). AA Balkema.

Wang, Y., Cui, Y. J., Tang, A. M., Benahmed, N., \& Duc, M. (2017). Effects of aggregate size on the compressibility and air permeability of lime-treated fine-grained soil. Engineering Geology, 228, 167-172. https://doi.org/10.1016/j.enggeo.2017.08.005

Yilmaz, Y. (2015). Compaction and strength characteristics of fly ash and fiber amended clayey soil. Engineering Geology, 188, 168-177. https://doi.org/10.1016/j.enggeo.2015.01.018 